\title{
Effect of rat urine (rattus norvegicus albinus) on the attractiveness and phagostimulants in the laboratory.
}

\author{
Rady, G. H*; Hafez, A.A*; Mahmoud, E.A**; Mohamed, Gh. R*. and Elbath, M.A*. \\ * Plant Protection Dept., Fac. of Agric., Moshtohor, Benha Univ. \\ ** Dept of Animal Hygiene Behaviour and Mangemen, Fac. of Veterinary \\ Medicine, Benha Univ.
}

*Corresponding author: moamen.elbath@fagr.bu.edu.eg

\begin{abstract}
This study was carried out on five males and ten females of Rattus norvegicus albinus (Berk) in the Plant Protection Dept; of Faculty of Agricultureat Moshtohor to investigate urine attraction in different development all stages of rats, as well the phagostimulant effect of urine that added to feed at two concentrations $10 \%$ and $20 \%$. Results indicated that urine of mature males were the most attractive type of mature, pregnant females, immature males and females. Howevere, urine of estrus females were the most attractive type of adult males, pregnant females, immature males and females. Regarding the phagostimulant effect of urine on feed consumption it was found that urine of adult males were the most attractive to adult females, while estrus urine was the most attractive to adult males. In case of immature males and females the lactating urine were the most effective urine. It also appeared that pregnant females were not affected by any type of urine.
\end{abstract}

Key word: Rat urine, Rattus norvegicus albinus (Berk), social behavior, attractiveness, phagostimulant.

\section{Introduction}

Rodents are considered one of the major pests of agricultural crops, stored food grains and poultry farms and may also adversely affect human health and cause great economic loss. Among rodents rats are the more dominant and highly infectious pests which infest human housing, sewers, animal shelters, daycare facilities, warehouses and outdoor recreational areas etc. Furthermore, they serve as a reservoir of several important pathogenic vectors of diseases like plague, leptospirosis, ricketsial pox,ratbite fever, marine typhus fever, and so on (Jackson, 1987).

Thus, efforts have been made to control rats by using chemical rodenticides, However, chemical control methods are made less effective by the rodent's bait shyness which lasts for several weeks or even months. So it is not effective to use rodenticide regularly and no specific method has overcome the poison bait shyness behavior of rodents. Attempts have been made to use urine to reduce the shyness behavior (Selvaraj and Archunan 2002).

Adding rat urine to poison bait successfully eliminates bait shyness behavior. This indicates that rat urine contains volatile compounds that are involved in reducing the poison bait shyness. It is not known whether a singleagent or a mixture of compounds present in the urine acts in reducing the bait shyness (Kumari and Prakash1980, 1988).

In many mammalian species, olfactory signals resulting from social interactions have been shown toplay a powerful role in the regulation of reproductive function. Especially, a special class of chemo-signals, known as pheromones, has been shown to regulate many aspects of reproductive physiology and behavior (Keller et al., 2012).

The present study aims to investigate the effect of rats urine on attractiveness and phagostimulant or adding rats urine (males, females mature and females pregnant and lactating during the first and third weeks of pregnancy and lactation) to non-poisons bait, on the platabilty and consumptions of conspecifics under laboratory.

\section{Material and Methods}

\section{Animals}

This work was carried out in the Plant Protection Department, Faculty of Agriculture, Benha University. Fifteen healthy adults (five males and ten females) white albino rat strain, Rattus norvegicus albinus (Berk) were obtained from the laboratory animal research center, Faculty of Veterinary Medicine, Benha University. The animals were housed in metallic cages ( five cages every cage contained one male and two females), supplied with enough food contain in $21 \%$ protein, $4.59 \%$ fat and $4.20 \%$ fiber and water. The animals were observed daily for about two weeks before any experiment. The healthy animal sexed, caged and given a refrence number, beside that number of mature albino rats, males and females let to multiplty.

\section{Urine collection}

The urine samples were collected from mature males and females, pregnant females during the first and 
third weeks of pregnancy, lactating females during the first and third weeks of lactation by a specific type of cages (metabolic cages). For urine collection from a group of rats (5 rats) were designed as a cylindrical shape with $30 \mathrm{~cm}$ depth and $25 \mathrm{~cm}$ diameter included a door at the top and the floor was grid in order to separate fecal matter from urine. Another cage with dimensions of 40x50x50 cm were designed for urine collection from a group of rats (30-50 rats).

\section{Testing the attractiveness of urine}

An odor preference test was conducted in amodified Y maze apparatus $(150 \times 15 \times 10 \mathrm{~cm})$, the sides and floor of amodified $\mathrm{Y}$ maze apparatus were made of tin sheets, while the top was covered with an iron mesh.The size of the center arm was about $75 \mathrm{~cm}$ long and $50 \mathrm{~cm}$ wide. The four branched arms were $75 \mathrm{~cm}$ long and $10 \mathrm{~cm}$ wide. Two clean glass slides were dipped in urine sample then put in branched arm number three and four, the tested rats were put in the central arm (male mature, female mature, male immature, female immature, andfemale pregnant) individually and given the opportunity to enter to any of the four passages. The number of visits and the time of spent near the urine sample by the test animals were assessed for ten minutes, the test was repeated three times for each animal.

Fifty grams of rat food were put in a plastic container and efficiently mixed with five $\mathrm{ml}$ liter of freshly collected urine samples. The food mixed with urine was put with the tested rats for twenty four hours for estimation of daily food consumption for each 100 gram body weight, then experiment was repeated again but by using $10 \mathrm{ml}$ of urine with 50 grams of food.

Statistical analysis of the obtained data was analyzed according to (SAS 1996), Differences between means were tested for significance according to (Dancan1955).

\section{Results and discussion}

\section{Effect of rat urine attraction on mature males and} females.

It is evident from data presented in (Table 1) that the time per second spent by the males rats for exploring the tested urine samples were $24.56,24.33,62.8$, $34.66,25.83,19.33,27,20.4,19.5,17.96,26.5$, 17.5 second / visit for mature male, mature female pregnant female during the first week of pregnancy, pregnant female during the third week of pregnancy, lactating female during the first week of lactation and lactating female during the third week of lactation, in the third and fourth passage respectively. The longest time spent by the adult male rat exploring the urine sample was that spent with adult female urine during estrus phase 62.8 , while the least attractive urine sample was that obtained from the lactating female in the third week of lactation 17.5.
Urine attraction may be due to the presence of different non-polar volatile compounds, which are known to stimulate their sexual behavior. These compounds collectively termed as pheromones that remain bound to some urinary proteins, which help in their signaling (Sunil et al. 2011) they are detected by male olfaction so female reproductive ability could be identified (Muroi et al. 2006 and Stopka $\boldsymbol{e t}$ al. 2007) its concentrations varied across reproductive cycles so facilitate to estrus detection by males (Achiraman et al. 2011). Similar results were also obtained by (Xiao et al. 2004) who found that sexually active male rats prefer the odor of receptive females over that ofovariectomized female. Male attraction is due to thepresence of many volatiles in its urine acted as a releaser pheromone and its production was under the control of androgen(Jemiolo et al. 1994)

From data presented in (Table 2) it is clear that the time per second spent by the mature females rats for exploring the tested urine samples were 36, 24.46, $46.43,27.66,16.33,18,20.7,19.06,12.03,9.33$, $12.36,9.2$ second / visit for mature male, mature female pregnant female during the first week of pregnancy, pregnant female during the third week of pregnancy, lactating female during the first week of lactation and lactating female during the third week of lactation, in the third and fourth passage respectively. The most attractive urine sample to the mature females was that taken from adult females during estrus phase 46.43 followed by that taken from the adult male $36 \pm 0.88$, while the least attractive urine sample was that taken from lactating females 9.2.

Chemical and behavioral studies were done to identify the volatiles in adult male rat urine that attract mature females. These results demonstrated that adult male rats have higher levels of 2-heptanone (2-HP), 4-methylphenol (4-MP), and 4-ethylphenol (4-EP) than prepubescent male rats. Furthermore, female rats are more attracted to the odor of adult male rat urine than that of prepubescent males, these results suggested that this attraction is may be due to an increased level of chemo signaling (Osada $\boldsymbol{e t}$ al. 2009). Other studies considered the attractiveness of the female to the male urine to females due to presence of a major urinary protein (MUP) named darcin in adult male urine (Roberts et al. 2010) which can promote female attraction (Roberts $\boldsymbol{e t}$ al. 2012).

Effect of rat urine on attraction of immature males and females.

From data presented in (Table 3) it is clear that the time per second spent by the immature males rats for exploring the tested urine samples were 42.76, 26.6, $36.83,35.8,14.96,20.1,20.36,23.26,21.83,18.86$, 26.66, 30.4 second / visit for mature male , mature female pregnant female during the first week of pregnancy, 
Table 1. Effect of rat urine on attraction of mature male.

\begin{tabular}{|c|c|c|c|c|c|c|c|c|c|c|c|c|}
\hline \multirow{2}{*}{ Treatment } & \multicolumn{3}{|c|}{ P1 } & \multicolumn{3}{|c|}{$\mathbf{P 2}$} & \multicolumn{3}{|c|}{ P3 } & \multicolumn{3}{|c|}{ P4 } \\
\hline & T1 & $\mathbf{N}$ & To.T & T2 & $\mathbf{N}$ & To.T & T3 & $\mathbf{N}$ & To.T & T4 & $\mathbf{N}$ & To.T \\
\hline UMM & $13.23 \pm 0.93^{\mathrm{de}}$ & 4 & 52.92 & $23,16 \pm 0,60^{a}$ & 2 & 46.32 & $24.56 \pm 0.93^{b}$ & 3 & 73.68 & $24.33 \pm 1.52^{b}$ & 4 & 97.32 \\
\hline UFE & $12.83 \pm 0.93^{e}$ & 4 & 51.32 & $16,5 \pm 0,60^{c}$ & 2 & 33 & $62.8 \pm 0.93^{a}$ & 3 & 188.4 & $34.66 \pm 1.52^{\mathrm{a}}$ & 4 & 138.64 \\
\hline UFPW1 & $19.23 \pm 0.93^{a b}$ & 4 & 76.92 & $13,96 \pm 0,60^{d}$ & 3 & 41.88 & $25.83 \pm 0.93^{b}$ & 2 & 51.66 & $19.33 \pm 1.52^{c}$ & 4 & 77.32 \\
\hline UFPW3 & $17.46 \pm 0.93^{b c}$ & 4 & 69.84 & $23,2 \pm 0,60^{\mathrm{a}}$ & 3 & 69.6 & $27 \pm 0.93^{b}$ & 2 & 54 & $20.4 \pm 1.52^{\mathrm{b}}$ & 4 & 81.6 \\
\hline UFLW1 & $15.93 \pm 0.93^{c d}$ & 3 & 47.79 & $20,66 \pm 0,60^{b}$ & 4 & 82.64 & $19.5 \pm 0.93^{c}$ & 2 & 39 & $17.96 \pm 1.52^{\mathrm{c}}$ & 4 & 71.84 \\
\hline UFLW3 & $21.23 \pm 0.93^{\mathrm{a}}$ & 3 & 63.69 & $15,96 \pm 0,60^{c}$ & 3 & 47.88 & $26.5 \pm 0.93^{b}$ & 2 & 53 & $17.5 \pm 1.52^{\mathrm{c}}$ & 4 & $\mathbf{7 0}$ \\
\hline
\end{tabular}

Table 2. Effect of rat urine on attraction of mature females.

\begin{tabular}{|c|c|c|c|c|c|c|c|c|c|c|c|c|}
\hline \multirow{2}{*}{ Treatment } & \multicolumn{3}{|c|}{$\mathbf{P 1}$} & \multicolumn{3}{|c|}{$\mathbf{P 2}$} & \multicolumn{3}{|c|}{ P3 } & \multicolumn{3}{|c|}{$\mathbf{P 4}$} \\
\hline & T1 & $\mathbf{N}$ & To.T & $\mathbf{T} 2$ & $\mathbf{N}$ & To.T & T3 & $\mathbf{N}$ & To.T & $\mathbf{T 4}$ & $\mathbf{N}$ & To.T \\
\hline UMM & $12.86 \pm 0.58^{b}$ & 5 & 64.3 & $0 \pm 0,54^{d}$ & 0 & 0 & $36 \pm 0.88^{b}$ & 5 & 180 & $24.46 \pm 1.23^{a}$ & 4 & 97.84 \\
\hline UFE & $14.03 \pm 0.58^{b}$ & 4 & 57.2 & $21 \pm 0,54^{\mathrm{a}}$ & 2 & 42 & $46.43 \pm 0.88^{a}$ & 4 & 185.72 & $27.66 \pm 1.23^{a}$ & 5 & 138.3 \\
\hline UFPW1 & $12.83 \pm 0.58^{b}$ & 4 & 51.32 & $18,66 \pm 0,54^{b}$ & 2 & 37.32 & $16.33 \pm 0.88^{d}$ & 2 & 32.66 & $18 \pm 1.23^{b}$ & 3 & 54 \\
\hline UFPW3 & $9.3 \pm 0.58^{c}$ & 4 & 37.2 & $18,33 \pm 0,54^{b}$ & 1 & 18.33 & $20.7 \pm 0.88^{c}$ & 2 & 41.4 & $19.06 \pm 1.23^{b}$ & 3 & $\mathbf{5 7 . 1 8}$ \\
\hline UFLW1 & $16.5 \pm 0.58^{a}$ & 2 & 33 & $16 \pm 0,54^{\mathrm{c}}$ & 2 & 32 & $12.03 \pm 0.88^{e}$ & 2 & 24.06 & $9.33 \pm 1.23^{c}$ & 4 & 37.32 \\
\hline UFLW3 & $16.6 \pm 0.58^{a}$ & 2 & 33.2 & $16,2 \pm 0,54^{\mathrm{c}}$ & 2 & 32.4 & $12.36 \pm 0.88^{e}$ & 2 & 24.72 & $9.2 \pm 1.23^{\mathrm{c}}$ & 4 & 36.8 \\
\hline
\end{tabular}

${ }^{*} \mathrm{P}=$ passage in $\mathrm{Y}$-maze apparatus.

$\mathrm{T}=$ the time spent in one visit. $\mathrm{N}=$ The number visits of passage.. To. $\mathrm{T}=$ total time spent in passage. ${ }^{* *} \mathrm{UMM}=$ Urine male mature $\quad$ UFE = Urine female estrus . UFPW1= Urine female pregnant during week1.UFPW3= Urine female pregnant during week3.

UFLW1= Urine female lactating during week1.

UFLW3= Urine female lactating during week 3

data are presented as means \pm standerderror.Mean followed by different letters in each column are significantly $(p<0.05)$ different 
Table 3. Effect of rat urine on attraction of immature male.

\begin{tabular}{|c|c|c|c|c|c|c|c|c|c|c|c|c|}
\hline \multirow{2}{*}{ treatment } & \multicolumn{3}{|c|}{ P1 } & \multicolumn{3}{|c|}{$\mathrm{P} 2$} & \multicolumn{3}{|c|}{ P3 } & \multicolumn{2}{|c|}{$\mathrm{P} 4$} & \multirow[b]{2}{*}{ To.T } \\
\hline & T1 & $\mathrm{N}$ & To.T & $\mathrm{T} 2$ & $\mathrm{~N}$ & To.T & T3 & $\mathrm{N}$ & To.T & T4 & $\mathrm{N}$ & \\
\hline UMM & $8.96 \pm 0.64^{\mathrm{e}}$ & 4 & 35.84 & $11,53 \pm 0,7^{b}$ & 3 & 34.59 & $42.76 \pm 0.94^{\mathrm{a}}$ & 3 & 128.28 & $26.6 \pm 0.98^{c}$ & 5 & 133 \\
\hline UFE & $20.23 \pm 0.64^{\mathrm{ab}}$ & 4 & 80.92 & $16,33 \pm 0,7^{\mathrm{a}}$ & 2 & 32.66 & $36.83 \pm 0.94^{b}$ & 4 & 147.32 & $35.8 \pm 0.98^{\mathrm{a}}$ & 4 & 143.2 \\
\hline UFPW1 & $15.03 \pm 0.64^{\mathrm{c}}$ & 4 & 60.12 & $1 \pm 0,7^{\mathrm{c}}$ & 1 & 1 & $14.96 \pm 0.94^{\mathrm{e}}$ & 3 & 44.88 & $20.1 \pm 0.98^{c}$ & 4 & 80.4 \\
\hline UFPW3 & $12.53 \pm 0.64^{\mathrm{d}}$ & 4 & 50.12 & $1,33 \pm 0,7^{\mathrm{c}}$ & 1 & 1.33 & $20.36 \pm 0.94^{\mathrm{d}}$ & 3 & 61.08 & $23.26 \pm 0.98^{\mathrm{d}}$ & 4 & 94.4 \\
\hline UFLW1 & $18.96 \pm 0.64^{b}$ & 3 & 56.88 & $16,1 \pm 0,7^{\mathrm{a}}$ & 3 & 48.3 & $21.83 \pm 0.94^{\mathrm{d}}$ & 2 & 43.66 & $18.86 \pm 0.98^{\mathrm{e}}$ & 4 & 75.44 \\
\hline UFLW3 & $21.33 \pm 0.64^{\mathrm{a}}$ & 3 & 63.99 & $15,96 \pm 0,7^{\mathrm{a}}$ & 3 & 47.88 & $26.66 \pm 0.94^{\mathrm{c}}$ & 2 & 53.32 & $30.4 \pm 0.98^{b}$ & 4 & 121.6 \\
\hline
\end{tabular}

Table 4. Effect of rat urine on attraction of immature female.

\begin{tabular}{|c|c|c|c|c|c|c|c|c|c|c|c|c|}
\hline \multirow{2}{*}{ treatment } & \multicolumn{3}{|c|}{$\mathrm{P} 1$} & \multicolumn{3}{|l|}{$\mathrm{P} 2$} & \multicolumn{3}{|c|}{ P3 } & \multicolumn{3}{|c|}{$\mathrm{P} 4$} \\
\hline & $\mathrm{T} 1$ & $\mathrm{~N}$ & To.T & $\mathrm{T} 2$ & $\mathrm{~N}$ & To.T & T3 & $\mathrm{N}$ & To.T & $\mathrm{T} 4$ & $\mathrm{~N}$ & To.T \\
\hline UMM & $14.63 \pm 1.6^{\mathrm{bc}}$ & 3 & 43.89 & $15,33 \pm 0,52^{b}$ & 2 & 30.66 & $34.4 \pm 0.8^{b}$ & 4 & 13.76 & $30.66 \pm 0.88^{\mathrm{a}}$ & 5 & 153.3 \\
\hline UFE & $13.46 \pm 1.6^{\mathrm{c}}$ & 5 & 67.3 & $21,73 \pm 0,52^{\mathrm{a}}$ & 3 & 65.19 & $37.03 \pm 0.8^{\mathrm{a}}$ & 4 & 148.12 & $33 \pm 0.88^{\mathrm{a}}$ & 4 & 132 \\
\hline UFPW1 & $19.16 \pm 1.6^{\mathrm{abc}}$ & 3 & 57.48 & $13,83 \pm 0,52^{\mathrm{bc}}$ & 2 & 27.66 & $18.5 \pm 0.8^{\mathrm{e}}$ & 3 & 74 & $13.76 \pm 0.88^{\mathrm{d}}$ & 5 & 68.8 \\
\hline UFPW3 & $15.53 \pm 1.6^{\mathrm{bc}}$ & 3 & 46.59 & $13,5 \pm 0,52^{c}$ & 1 & 13.5 & $22.6 \pm 0.8^{\mathrm{d}}$ & 3 & 67.8 & $18.4 \pm 0.88^{\mathrm{c}}$ & 5 & 92 \\
\hline UFLW1 & $17.4 \pm 1.6^{\mathrm{ab}}$ & 3 & 52.2 & $14,93 \pm 0,52^{\mathrm{bc}}$ & 3 & 44.79 & $18.5 \pm 0.8^{\mathrm{e}}$ & 2 & 37 & $24.33 \pm 0.88^{b}$ & 4 & 97.32 \\
\hline UFLW3 & $21.23 \pm 1.6^{\mathrm{a}}$ & 3 & 63.69 & $0 \pm 0,52^{\mathrm{d}}$ & 0 & 0 & $30.5 \pm 0.8^{c}$ & 2 & 61 & $24.86 \pm 0.88^{\mathrm{b}}$ & 5 & 124.3 \\
\hline
\end{tabular}

Table 5. Effect of rat urine on attraction of pregnant female.

\begin{tabular}{|c|c|c|c|c|c|c|c|c|c|c|c|c|}
\hline \multirow{2}{*}{ treatment } & \multicolumn{3}{|c|}{ P1 } & \multicolumn{3}{|c|}{$\mathrm{P} 2$} & \multicolumn{3}{|c|}{ P3 } & \multicolumn{3}{|c|}{$\mathrm{P} 4$} \\
\hline & $\mathrm{T} 1$ & $\mathrm{~N}$ & To.T & $\mathrm{T} 2$ & $\mathrm{~N}$ & To.T & $\mathrm{T} 3$ & $\mathrm{~N}$ & To.T & $\mathrm{T} 4$ & $\mathrm{~N}$ & To.T \\
\hline UMM & $11.83 \pm 0.58^{\mathrm{d}}$ & 3 & 35.49 & $3,66 \pm 0,86^{\mathrm{c}}$ & 1 & 3.66 & $23.7 \pm 0.74^{\mathrm{d}}$ & 3 & 71.1 & $32 \pm 0.87^{\mathrm{a}}$ & 4 & 128 \\
\hline UFE & $14.86 \pm 0.58^{c}$ & 3 & 44.58 & $19,66 \pm 0,86^{\mathrm{a}}$ & 2 & 39.32 & $40.5 \pm 0.74^{\mathrm{a}}$ & 3 & 121.5 & $33.93 \pm 0.87^{\mathrm{a}}$ & 4 & 135.72 \\
\hline UFPW1 & $21.5 \pm 0.58^{\mathrm{a}}$ & 3 & 64.5 & $15,96 \pm 0,86^{\mathrm{b}}$ & 3 & 47.88 & $27 \pm 0.74^{\mathrm{c}}$ & 2 & 54 & $17.56 \pm 0.87^{b}$ & 4 & 70.24 \\
\hline UFPW3 & $18.16 \pm 0.58^{b}$ & 3 & 54.48 & $13,96 \pm 0,86^{\mathrm{b}}$ & 3 & 41.88 & $31.16 \pm 0.74^{b}$ & 2 & 62.32 & $19.23 \pm 0.87^{b}$ & 4 & 76.92 \\
\hline UFLW1 & $11.93 \pm 0.58^{\mathrm{d}}$ & 3 & 35.79 & $14,33 \pm 0,86^{\mathrm{b}}$ & 2 & 28.66 & $10.1 \pm 0.74^{\mathrm{e}}$ & 2 & 20.2 & $10.06 \pm 0.87^{\mathrm{c}}$ & 4 & 40.24 \\
\hline UFLW3 & $16.5 \pm 0.58^{c}$ & 2 & 33 & $16,03 \pm 0,86^{\mathrm{b}}$ & 2 & 32.06 & $11 \pm 0.74^{\mathrm{e}}$ & 3 & 33 & $9.86 \pm 0.87^{\mathrm{c}}$ & 2 & 19.72 \\
\hline
\end{tabular}

apparatus. $\quad \mathrm{T}=$ the time spent in one visit. $\quad \mathrm{N}=$ The number visits of passage.. $\quad$ To.T $=$ total time spent in

passage. $\quad{ }^{* *} \mathrm{UMM}=$ Urine male mature . $\quad$ UFE $=$ Urine female estrus . UFPW1= Urine female pregnant during

week1. UFPW3= Urine female pregnant during week3. UFLW1= Urine female lactating during week1.

UFLW3= Urine female lactating during week 3

data are presented as means \pm standerd error. Mean followed by different letters in each column are significantly $(p<0.05)$

differen. 
pregnant female during the third week of pregnancy, lactating female during the first week of lactation and lactating female during the third week of lactation, in the third and fourth passage respectively. The most attractive urine sample to the immature males was that taken from mature male 42.76 followed by that collected from adult females during estrus phase 36.83 , while the least effective urine sample was that collected from pregnant females in the first week of pregnancy 14.96. Obtaned results proved presence of odor preference in immature rats so it is agreed with those obtained by Carr et al. 1970 who found that immature males preferred normal over castrated male odors $(\mathrm{p}<.05)$ and Agmo 2003 who found that sexually inexperienced male rats (Rattus norvegicus) when exposed to the receptive female-male incentives, they spent more time close to the female. If the incentives were receptive female with a nonreceptive female, the receptive female was preferred castration abolished preference for the receptive female, and treatment with testosterone propionate restored it. But not agree with (Stern, 1970) who found absence of odor preference for naive or castrated males assexually experienced male rats which preferred the odor from receptive females over that from non receptive.

It is evident from data presented in (Table 4) that the timeper second spent by the immature females rats for exploring the tested urine samples were $34.4,30.66,37.03,33,18.5,13.76,22.6,18.4$, $18.5,24.33,30.5,4.86$ / second for mature male , mature female pregnant female during the first week of pregnancy, pregnant female during the third week of pregnancy, lactating female during the first week of lactation and lactating female during the third week of lactation, in the third and fourth passage respectively.The most attractive urine sample to the immature females was that taken from adult females during estrus phase 37.03 and adult male 34.4 , while the least effective one was that taken from pregnant females during the first week of pregnancy 13.76 . These results proved that immature females have the ability to detect pheromones and this effect appeared from the experiments of (Drickamer, 1984) who tested the acceleration of puberty in young female mice treated with urine from pregnant or lactating females and (Drickamer, 1988) who mentioned that oestrous females released a substance in their urine that accelerates puberty in young females.

\section{Effect of rat urine on attraction of pregnant females.}

From data presented in (Table 5) it is shown that the time per second spent by the pregnant females rats for exploring the tested urine samples were 23.7, 32, 40.5, 33.93, 27, 17.56, 31.16, 19.23,10.1, 10.06, 11, 9.86 second / visit for mature male , mature female pregnant female during the first week of pregnancy, pregnant female during the third week of pregnancy, lactating female during the first week of lactation and lactating female during the third week of lactation in the third and fourth passage respectively. The most attractive urine sample to the pregnant females was that taken from estrus females 40.5 followed by that collected from adult male 32, while the least attractive urine sample was that obtained from lactating females in the first week of lactation 10.1.These results may be due to the effect of reproductive state of animal on the sensitivity of olfaction and pheromone concentration released through urine, sweat, saliva and feces as mentioned by (Achiraman et al. 2011).

\section{Effect of rat urine mixed with food on food consumption of rat.}

Result obtained from addition of urine by two concentrations (10 and 20\%) to food of rat in (Table 6 and 7) revealed that food consumption in the adult male when mixed with urine of mature male, mature female pregnant femaleduring the first week of pregnancy, pregnant female during the third week of pregnancy, lactating female during the first week of lactation and lactating female during the third week of lactation were $11.6,14,9.9,10,11,10.9,9.4$ and $12.4,15,10.5,10.8,10.7,11.9,9.7 \mathrm{~g} / 100 \mathrm{~g}$ body weight for two concentrations (10\% and 20\%) respectively, while food consumptions were 14, 11.4, $8.9,9,9.5,8.7,10.1$ and $15,13.6,9.5,9.6,9.9,8.2$, $9.7 \mathrm{~g} / 100 \mathrm{~g}$ body weight in case of mature female when its food was mixed with urine of mature male, mature female pregnant female during the first week of pregnancy, pregnant female during the third week of pregnancy, lactating female during the first week of lactation and lactating female during the third week of lactation by the two concentrations $10 \%$ and $20 \%$. In the immature Male it was 8.9, 10.2, 9.2, 9.1, 12.6, 12.19.2and 9.1, 11.2, 9.3, 9, 13.2, 11.5, 10g/100 $\mathrm{g}$ body weight for two concentrations (10\% and $20 \%)$ respectively. When its food was mixed with urine of mature male, mature female pregnant female during the first week of pregnancy, pregnant female during the third week of pregnancy, lactating female during the first week of lactation and lactating female during the third week of lactation by the two concentrations $10 \%$ and $20 \%$ in immature female it was $10.1 \pm 0.09,9.9 \pm 0.09,10,10.1,12.1,11.5,9.4$ and $10,10.2,9.8,10.5,12.9,12.1,9 \mathrm{~g} / 100 \mathrm{~g}$ body weight for two concentrations (10\% and $20 \%$ )respectively. When its food was mixed with urine of mature male , mature female pregnant female during the first week of pregnancy, pregnant female during the third week of pregnancy, lactating female during the first week of lactation and lactating female during the third week of lactation by the two concentrations $10 \%$ and $20 \%$ in pregnant female it was $8,9,8.1,8.3$, $9.1,8.8,8.7$ and $7.5,9,8.5,9.1,9.5,9,9.4 \mathrm{~g} / 100 \mathrm{~g}$ body weight for two concentrations (10\% and 20\%) respectively. 
Table 6.Effect of the type of urine mixed with food (10\% concentrate) on Food consumption in rat.

\begin{tabular}{|c|c|c|c|c|c|}
\hline \multirow{2}{*}{ "Treatment } & \multicolumn{5}{|c|}{ Sex } \\
\hline & male mature & female mature & Male immature & female immature & female pregnant \\
\hline UMM & $11.6 \pm 0.11^{\mathrm{b}}$ & $14 \pm 0.09^{\mathrm{a}}$ & $8.9 \pm 0.1^{\mathrm{d}}$ & $10.1 \pm 0.09^{\mathrm{c}}$ & $8 \pm 0.1^{\mathrm{b}}$ \\
\hline UFE & $14 \pm 0.11^{\mathrm{a}}$ & $11.4 \pm 0.09^{\mathrm{b}}$ & $10.2 \pm 0.1^{\mathrm{c}}$ & $9.9 \pm 0.09^{c}$ & $9 \pm 0.1^{\mathrm{a}}$ \\
\hline UFPW1 & $9.9 \pm 0.11^{\mathrm{d}}$ & $8.9 \pm 0.09^{\mathrm{ef}}$ & $9.2 \pm 0.1^{\mathrm{d}}$ & $10 \pm 0.09^{c}$ & $8.1 \pm 0.1^{b}$ \\
\hline UFPW3 & $10 \pm 0.11^{\mathrm{d}}$ & $9 \pm 0.09^{\mathrm{e}}$ & $9.1 \pm 0.1^{\mathrm{d}}$ & $10.1 \pm 0.09^{c}$ & $8.3 \pm 0.1^{\mathrm{b}}$ \\
\hline UFLW1 & $11 \pm 0.11^{\mathrm{c}}$ & $9.5 \pm 0.09^{d}$ & $12.6 \pm 0.1^{\mathrm{a}}$ & $12.1 \pm 0.09^{\mathrm{a}}$ & $9.1 \pm 0.1^{\mathrm{a}}$ \\
\hline UFLW3 & $10.9 \pm 0.11^{\mathrm{c}}$ & $8.7 \pm 0.09^{\mathrm{f}}$ & $12.1 \pm 0.1^{\mathrm{b}}$ & $11.5 \pm 0.09^{b}$ & $8.8 \pm 0.1^{\mathrm{a}}$ \\
\hline Water (control) & $9.4 \pm 0.11^{\mathrm{e}}$ & $10.1 \pm 0.09^{\mathrm{c}}$ & $9.2 \pm 0.1^{\mathrm{d}}$ & $9.4 \pm 0.09^{\mathrm{d}}$ & $8.7 \pm 0.1^{\mathrm{a}}$ \\
\hline
\end{tabular}

Table 7.Effect of the type of urine mixed with food (20\% concentrate) on Food consumption in rat.

\begin{tabular}{|c|c|c|c|c|c|}
\hline \multirow{2}{*}{ Treatment } & \multicolumn{5}{|c|}{ Sex } \\
\hline & male mature & female mature & Male immature & female immature & female pregnant \\
\hline UMM & $12.4 \pm 0.1^{\mathrm{b}}$ & $15 \pm 0.1^{\mathrm{a}}$ & $9.1 \pm 0.09^{\mathrm{e}}$ & $10 \pm 0.11^{\mathrm{d}}$ & $7.5 \pm 0.05^{\mathrm{d}}$ \\
\hline UFE & $15 \pm 0.1^{\mathrm{a}}$ & $13.6 \pm 0.1^{b}$ & $11.2 \pm 0.09^{\mathrm{c}}$ & $10.2 \pm 0.11^{\mathrm{cd}}$ & $9 \pm 0.05^{\mathrm{b}}$ \\
\hline UFPW1 & $10.5 \pm 0.1^{\mathrm{d}}$ & $9.5 \pm 0.1^{\mathrm{d}}$ & $9.3 \pm 0.09^{\mathrm{e}}$ & $9.8 \pm 0.11^{\mathrm{d}}$ & $8.5 \pm 0.05^{\mathrm{c}}$ \\
\hline UFPW3 & $10.8 \pm 0.1^{\mathrm{d}}$ & $9.6 \pm 0.1^{\mathrm{cd}}$ & $9 \pm 0.09^{\mathrm{e}}$ & $10.5 \pm 0.11^{\mathrm{c}}$ & $9.1 \pm 0.05^{b}$ \\
\hline UFLW1 & $10.7 \pm 0.1^{\mathrm{d}}$ & $9.9 \pm 0.1^{\mathrm{c}}$ & $13.2 \pm 0.09^{\mathrm{a}}$ & $12.9 \pm 0.11^{\mathrm{a}}$ & $9.5 \pm 0.05^{\mathrm{a}}$ \\
\hline UFLW3 & $11.9 \pm 0.1^{\mathrm{c}}$ & $8.2 \pm 0.1^{\mathrm{e}}$ & $11.5 \pm 0.09^{b}$ & $12.1 \pm 0.11^{\mathrm{b}}$ & $9 \pm 0.05^{\mathrm{b}}$ \\
\hline Water (control) & $9.7 \pm 0.1^{\mathrm{e}}$ & $9.7 \pm 0.1^{\mathrm{cd}}$ & $10 \pm 0.09^{\mathrm{d}}$ & $9 \pm 0.11^{\mathrm{e}}$ & $9.4 \pm 0.05^{\mathrm{a}}$ \\
\hline
\end{tabular}

*UMM=Urine male mature.

UFPW1= Urine female pregnant during week1.

UFE $=$ Urine female estrus

UFLW1 $=$ Urine female lactating during week 1 .

UFPW3= Urine female pregnant during week 3 .

3.data are presented as means \pm standerd error.

UFLW3 = Urine female actating during week

Mean followed by different letters in each column are significantly $(\mathrm{p}<0.05)$ different 
From the previous results it is evident that food consumption was increased in the mature female when their food was mixed with adult male urine by the two concentrations, while food consumption was increased in mature males when their food was mixed with estrus urine. In case of immature males and females the more stimulant urine was that of the lactating female in the first stage of lactation. Regarding food consumption in the pregnant female, it was not affected by addition of any urine. In all cases food consumption was increased when food was mixed with urine by $20 \%$ than when added by $10 \%$. These results indicate that urine has phagostimulant action in both sexes, whether mature or immature, it also demonstrated that urine-treated food is more palatable for rats of different sex-groups than those of the same sex-group, a result which is useful practically for attracting males to traps or to mask poison bait shyness hence increasing the poison bait consumption or acceptance and consequently the mortality of rats. These results are similar to those obtained by (Omar et al. 1990) who mentioned that urine treated food was more palatable than untreated food for all rat groups. On the other hand palatability was higher when rat urine was collected from different sex groups than from the same sex group so bait acceptance were greatly improved once. Also in accordance with (McGregor $\boldsymbol{e t}$ al. 2004) who stated that the conditioned taste aversion exhibited by rats is associated with taste memory which may act negatively on bait acceptance, in this situation addition of apheromonalodours produced from conspecifics may probably alter or minimize the taste memory so increase the acceptance of the poison bait relatively better.

\section{Acknowledgement}

The authors acknowledge to the Talented Young scientists Programme of Benha University, Egypt (Ecofriendly approaches for controlling economic agriculture of pests).

\section{References}

Achiraman, S.;Archunan, G.;Sankarganesh, D.;Rajagopal, T.; Rengarajan, RL.;Kokilavani, P.;Kamalakkannan, S.; and Kannan, S. (2011). Biochemical analysis of female mice urine with reference to endocrine function: a key tool for estrus detection. Zoological Science 28(8):600-605.

Agmo, A. (2003). Unconditioned sexual incentive motivation in the male Norway Rat (Rattus norvegicus). Journal of Comparative Psychology. 117(1): 3-14.

Carr, W.J.; Wylie, N.R.; Loeb, L.S. (1970). Journal of Comparative and Physiological Psychology. 72(1): 51-59
Drickamer, LC. (1984). Acceleration of puberty in female mice by a urinary chemosignal from pregnant or lactating females: timing and duration of stimulation. Developmental Psychobiology. 17(5):451-455.

Drickamer, LC. (1988). Acceleration and delay of sexual maturation in female house mice (Musdomesticus) by urinary chemosignals: mixing urine sources in unequal proportions. Journal of Comparative Psychology 102(3):215-221.

Duncan, D.B. (1955). Multiple range and multiple f. test J.B Biometries, 11(1).

Jackson, W.B. (1987). Current management studies for commensal rodents. In HH Genoways.ed. Current mammalogy.Vol. 1. New York: Plenum Publishing. pp.495-512.

Jemiolo, B.;Gubernick, D.J.;Catherine Yoder, M.andNovotny, M. (1994). Chemical characterization of urinary volatile compounds ofPeromyscuscalifornicus.a monogamous biparentalrodent.Journal of Chemical Ecology. 20(10):2489-2500.

Keller,M;Bedos,M;Jouhanneau,M; Martini,M;Retana-Márquez,S and Delgadillo,J. (2012). Pheromonal modulation of reproductive function in mammals . Tropical and Subtropical Agroecosystems, 15 (1): S103 $-\mathrm{S} 111$

Kumari, S. and Prakash, I. (1980). Role of conspecific urine in enhancing food consumption and masking of shyness behaviour in the desert gerbil.M. hurriane (Jerdon). Indian J. Exp. Biol. 18: 730-732.

Kumari, S. and Prakash.I. (1988). Relative efficacy of male and female conspecific urine in masking shyness behaviour in Indian gerbil.Tateraindica. Indian Acad. Sci. (Anim. Sci.) 93: 431- 436.

Mcgregor, I.S.; Hargreaves, G.A.; Apfelbach, R. and Hunt, G.E. (2004). Neural correlates of cat odor-induced anxiety in rats: region-specific effects of the benzodiazepine midazolam. J Neurosci 24:4134-4144.

Muroi, Y.;Ishii, T.;Komori, S.andNishimura, M.(2006). A competitive effect of androgen signaling on male mouse attraction to volatile female mouse odors. Physiology Behavior 87(1):199-205.

Omar, A.M.; El-sherbiny, A.H.; El-Deeb, H.I. and El-Halfawy, M. (1990). Laboratory studies on the function of rat urine as aphagostimulant.Assiut Journal of Agricultural Sciences.21(4).1990.

Osada, K.;Kashiwayanagi, M.; and Izumi, H. (2009). Profiles of volatiles in male rat urine: the effect of puberty on the female attraction. Chemical Senses. 34(8):713-721.

Roberts, S.A.; Davidson, A.J.; McLean, L.;Beynon, R.J. and Hurst, J.L. 
(2012).Pheromonal Induction of Spatial Learning in Mice.Science. 338. 1462-1465.

Roberts, S.A.; Simpson, D.M.; Armstrong, S.D.; Davidson, A.J.; Robertson, D.H.; McLean, L.;Beynon, R.J. and Hurst, J. L. (2010).Darcin: a male pheromone that stimulates female memory and sexual attraction to an individual male's odour. Bmc Biology. 8 . 75 .

Sas (1996). SAS procedure guide " version 6.12 Ed. " SAS institute Inc., cary, Nc,USA.

Stern, J.J. (1970). Responses of male rats to sex odors. Physiol. Behav. 5:519-524.
Stopka, P.; Janotova, K. andHeyrovsky, D. (2007).The advertisement role of major urinary proteins in mice.Physiology\& Behavior. 91(5):667-670.

Sunil Kumar, B.V.; Kataria, M. and Meur, S. K. (2011).Detection of Protein Bound Volatile Compounds in Buffalo Urine. Journal of Advanced Veterinary Research (1) 21-23.

Xiao, K.; Kondo, Y. and Sakuma, Y. (2004). Sexspecific effects of gonadal steroids on conspecific odor preference in the rat. Horm.Behav. (46) 356-361.

تأثير البوال الفار ( Rattus norvegicus albinus ) علي علية الجذب وزيادة استصاغة الطعام في المعمل

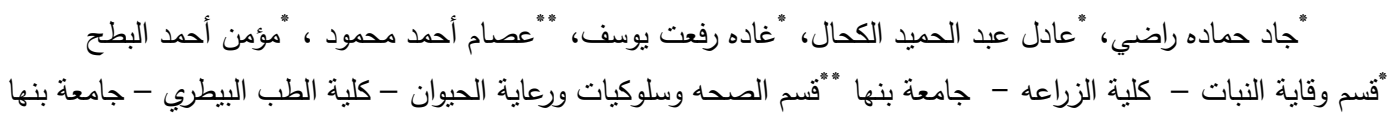

اجريت هذه الدراسة فى قسم وقاية النبات بلية الزراعه بمشتهر على عدد خمس ذكور وعثر اناث فأر ابيض من سلالة الويستر وذلك بغرض

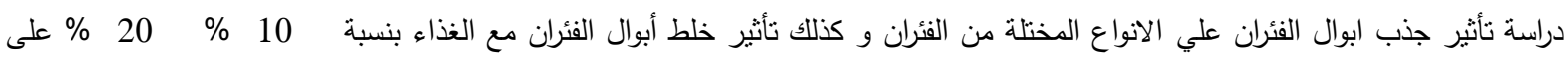
معدل استهلاك الغذاء وقد خلصت الدراسة الى النتائج الثالية: سجل ابوال الذكور البالغة اسرع معدل جذب للاناث البالغة والحوامل (183. و 128 ثانيه ) علي التوالي وكذللك الذكور و الاناث غير البالغة ( 133 و 153.3 ثانيه ) علي التوالي. سجل بول الاناث البالغه فى فترة الثبق اسرع معدل جذب للذكور البالغة والاناث الحوامل ( 188 و 135.7 ثانيه ) علي النوالي وكنلك

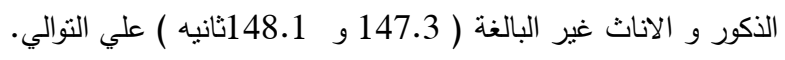

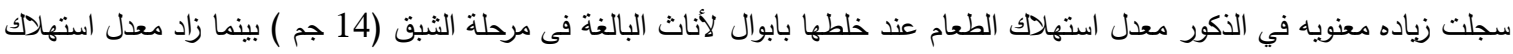

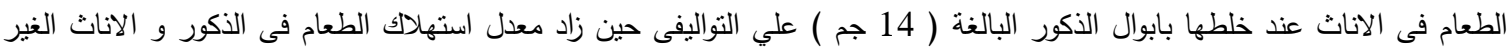

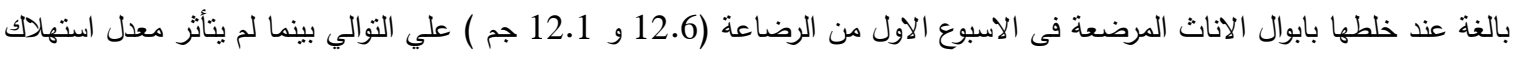

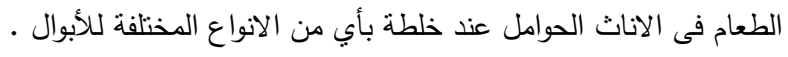

